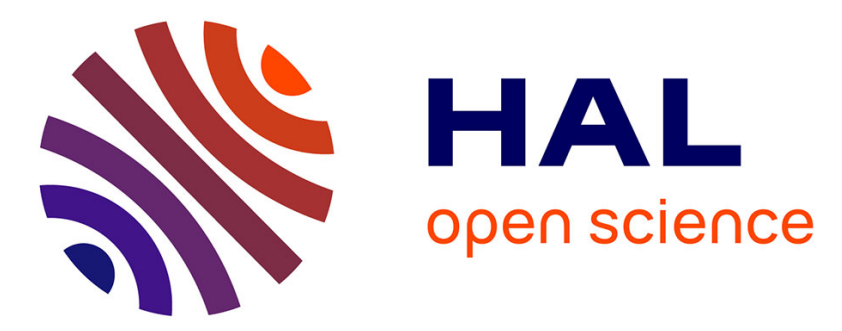

\title{
Total Synthesis of Rhazinilam through Gold-Catalyzed Cycloisomerization-Sulfonyl Migration and Palladium-Catalyzed Suzuki-Miyaura Coupling of Pyrrolyl Sulfonates
}

\author{
Fatih Sirindil, Jean-Marc Weibel, Patrick Pale, Aurelien Blanc
}

\section{To cite this version:}

Fatih Sirindil, Jean-Marc Weibel, Patrick Pale, Aurelien Blanc. Total Synthesis of Rhazinilam through Gold-Catalyzed Cycloisomerization-Sulfonyl Migration and Palladium-Catalyzed SuzukiMiyaura Coupling of Pyrrolyl Sulfonates. Organic Letters, 2019, 21 (14), pp.5542-5546. 10.1021/acs.orglett.9b01860 . hal-02347237

\section{HAL Id: hal-02347237 \\ https://hal.science/hal-02347237}

Submitted on 5 Nov 2019

HAL is a multi-disciplinary open access archive for the deposit and dissemination of scientific research documents, whether they are published or not. The documents may come from teaching and research institutions in France or abroad, or from public or private research centers.
L'archive ouverte pluridisciplinaire HAL, est destinée au dépôt et à la diffusion de documents scientifiques de niveau recherche, publiés ou non, émanant des établissements d'enseignement et de recherche français ou étrangers, des laboratoires publics ou privés. 


\title{
Total Synthesis of Rhazinilam through Gold-Catalyzed Cycloisomerization-Sulfonyl Migration \& Palladium-Catalyzed Suzu- ki-Miyaura Coupling of Pyrrolyl Sulfonates
}

\author{
Fatih Sirindil, Jean-Marc Weibel, Patrick Pale and Aurélien Blanc*
}

Laboratoire de Synthèse, Réactivité Organiques et Catalyse, Institut de Chimie, UMR 7177 - CNRS, Université de Strasbourg, 4 rue Blaise Pascal, 67070 Strasbourg, France.

Supporting Information Placeholder

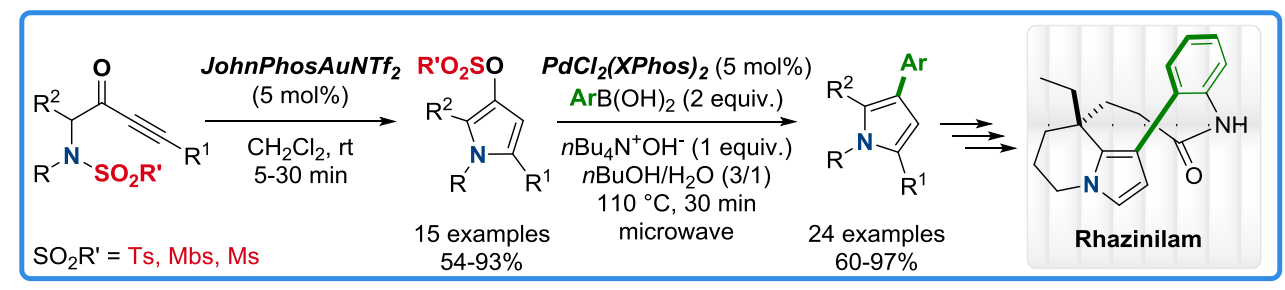

\begin{abstract}
We report the first general conditions for the challenging Suzuki-Miyaura reaction with pyrrole-related sulfonate coupling partners (24 examples, 60-97\%). Bis(dichloro)bis(2-dicyclohexylphosphino-2',4',6'-triiso-propylbiphenyl) palladium(II) precatalyst ensures the high efficiency of the reaction. The total synthesis of rhazinilam, a monoterpenoid indole alkaloid, highlights such cross-coupling as well as the simple preparation of pyrrolyl sulfonates by $N$-to- $O$ 1,5-sulfonyl migration catalyzed by gold(I) (15 examples, 54-93\%).
\end{abstract}

\begin{abstract}
Alkaloids constitute a huge family of natural products. Among them, monoterpene indole alkaloids exhibit a large structural diversity and a wide range of pharmacological properties. ${ }^{1}$ This alkaloid subfamily has provided several useful anticancer compounds. Isolated from the plants Rhazya stricta, Melodinus australia and Kopsia sp., respectively growing in the desertic parts of Iraq and the Arabic peninsula and in Oceania, rhazinilam ${ }^{2}$ is one of these anticancer alkaloids (Scheme 1 , top). It exhibits taxol-like activity in inhibiting microtubule assembly and disassembly, ${ }^{3}$ and further studies revealed that it also promotes the formation of abnormal tubulin spirals. ${ }^{4}$ These unique biological activities in the low micromolar range $\left(\mathrm{IC}_{50} 0.6-1.2 \mu \mathrm{M}\right)$ together with a unique structure have initiated several total syntheses of rhazinilam and analogs, often aimed at developing new anticancer drugs.
\end{abstract}

Within the various approaches reported in the literature, ${ }^{5}$ the controlled formation of the tetrahydroindolizine core, the anilinopyrrole motif or the quaternary center has represented the most important challenge.

The gold-catalyzed cycloisomerization-sulfonyl migration cascade we recently discovered ${ }^{6}$ offers a unique opportunity to design a new synthetic route to rhazinilam and related natural compounds (Step A, Scheme 1, bottom). ${ }^{7}$ This gold-promoted cascade could indeed efficiently provide the rhazinilam pyrrole core, ready for an unprecedented Suzuki-Miyaura-type coupling reaction (Step B). A further oxidative Heck-type reaction (Step $\mathrm{C}$ ) between a prepositioned alkene function and the pyrrole core would give the tricyclic structure ready for macrolactamization, while forming the quaternary center. ${ }^{8}$

Scheme 1. Planned Strategy towards the Synthesis of Rhazinilam Based on Gold-Catalyzed Cascade and SuzukiMiyaura Coupling of Pyrrolyl Sulfonates.

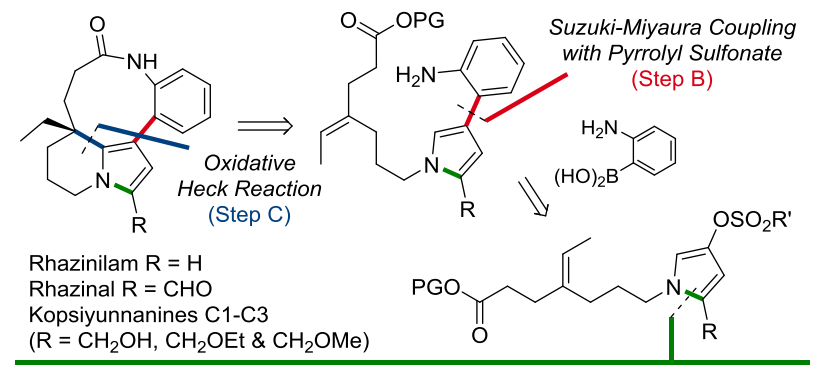

This work: Improved \& Extended Gold-Catalyzed Cyclization/Sulfonyl Migration

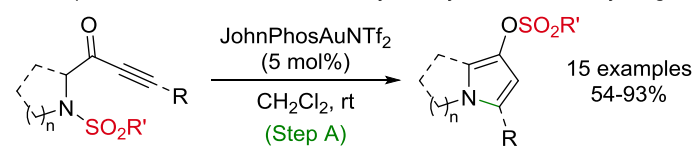

To implement this strategy, our gold-catalyzed cycloisomerization-sulfonyl migration cascade must first be extended to acyclic 1-aminobut-3-yn-2-ones to produce 1,2,4trisubstituted pyrrolyl sulfonates. Second, the Suzuki-Miyaura coupling reaction of pyrrolyl tosylates and related sulfonates must be developed. Indeed, only a handful of such reactions 
involving $N$-heterocyclic sulfonates other than triflate have so far been reported and none of pyrrolyl sulfonates (Scheme 2). ${ }^{9}$ We therefore investigated these reactions and we reported here our results, including the new palladium-catalyzed coupling of pyrrolyl sulfonates, as well as their application to a concise total synthesis of rhazinilam.

Scheme 2. Suzuki-Miyaura Palladium Coupling of $N$ Heteroaryl Tosylates with Boronic Acids.

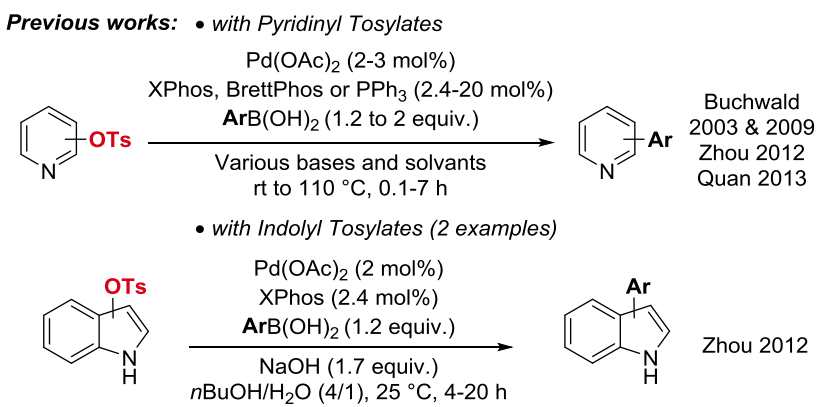

This work: $\quad$ - First examples with Pyrrolyl Tosylates

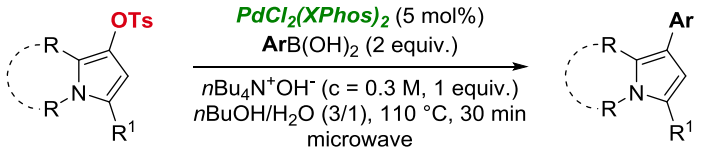

In order to validate the above-mentioned strategy, step A was first investigated. Various $N$-alkylated $N$-sulfonyl 1 aminobut-3-yn-2-ones 1 were prepared from methyl glycinate (see Supporting Information), including examples carrying $\mathrm{N}$ pent-4-enyl chain as models of the precursor required for the rhazinilam synthesis (Step C). They were then submitted to the conditions we developed for the gold-catalyzed cycloisomerization-sulfonyl migration reaction and various gold catalysts were briefly surveyed. Although the Gagosz catalyst $\left(\mathrm{PPh}_{3} \mathrm{AuNTf}_{2}\right)$ gave good results for the formation of dihydropyrrolizines ${ }^{6}$, JohnPhosAuNTf 2 proved to be more efficient with acyclic as well as cyclic substrates 1 (Scheme 3). Within 5-10 minutes, they were converted to the expected sulfonylated pyrroles 2 a-f in high yields $(80-93 \%)$. The yield was slightly lower with a simple $N$-benzyl chain due to the instability of compound $\mathbf{2 d}$. Because in the rhazinilam synthesis the steps B and C (Scheme 1) could be inverted, $N$-sulfonyl pyrrolidines and piperidines carrying a 1-oxo-2-propynyl chain were also prepared and submitted to the abovementioned conditions. The expected sulfonylated di- or tetrahydro pyrrolizines or indolizines $\mathbf{2 g}-\mathbf{n}$ were efficiently produced in good to excellent yields.

It is worth noticing that such methodology is fully compatible with various sulfonyl groups, including tosylates (Ts), para-methoxybenzenesulfonates (Mbs), mesylates (Ms) and nosylates (Ns) which provide the best results (78-96\%) generally within minutes, while triflates (Tf) were ineffective in this cascade (see $\mathbf{2 l}$ vs $\mathbf{2 h - k}$ ). These results clearly enlarge the scope of our gold-catalyzed cycloisomerization-sulfonyl migration cascade and open the stage for the planned rhazinilam synthesis.
Scheme 3. Scope of the Gold(I)-Catalyzed Cycloisomerization-Sulfonyl Migration Cascade Starting from $N$-Sulfonyl 1-Aminobut-3-yn-2-ones 1.

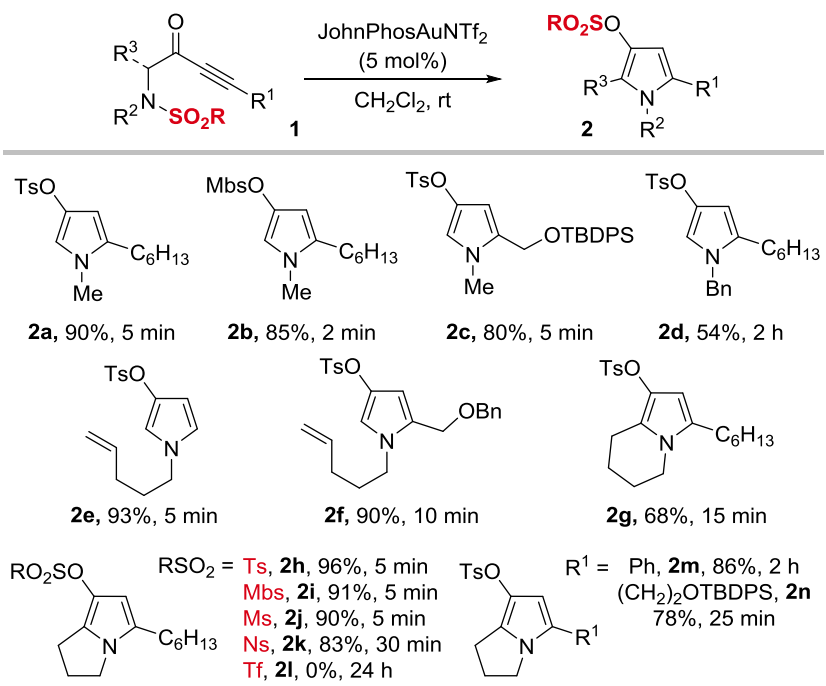

Ts = Tosyl; Mbs = 4-Methoxybenzenesulfonyl; Ms = Mesyl; Ns = Nosyl; $\mathrm{Tf}=$ Triflate.

The Suzuki-Miyaura reaction between boronic acids and pyrrolyl sulfonates $\mathbf{2}$ was then investigated. This crosscoupling was challenging considering the difficulty to perform the oxidative addition of $\operatorname{Pd}(0)$ to electron- rich $N$-sulfonated pyrroles, and the ability of $N$-heterocyles to displace phosphine ligands to form stable palladium(II) complexes. ${ }^{10}$

The pyrrolyl tosylate $\mathbf{2 h}$, easily obtained in few steps on gram scale from proline, was selected for the optimization work (see Supporting Information). Applying the conditions reported for related $N$-heterocyclic tosylates (Scheme 2) did not give the expected products. Screening palladium sources and ligands revealed bis(acetonitrile)palladium dichloride and $\mathrm{XPhos}$ as the best combination toward an active catalyst. However, the base nature turned out to be crucial, as well as its concentration, in agreement with the delicate balance the base plays with the boron coupling agent and at the transmetallation step in Suzuki-Miyaura coupling. ${ }^{11}$ Furthermore, reproducibility issues were faced (Eq. 1 in Scheme 4). Inspired by studies from the Hartwig and Buchwald groups, which showed that in certain couplings, ${ }^{12}$ it is beneficial to independently prepare the actual catalyst rather than produce it in situ, ${ }^{13}$ we screened several preformed catalysts and found that $\mathrm{PdCl}_{2}(\mathrm{XPhos})_{2}$ gave the best results in butanol-water in the presence of one equivalent of tetrabutylammonium hydroxide as base (Eq. 1 Scheme 4). Surprisingly almost unknown, ${ }^{14} \mathrm{PdCl}_{2}$ (XPhos) $)_{2}$ was easily obtained by heating bis(acetonitrile)palladium dichloride and XPhos in acetonitrile (Eq. 2 in Scheme 4).

With an effective catalyst and the right conditions in hand, we then explored the scope of this unprecedented transformation. Monocyclic as well as bicyclic pyrrolyl sulfonates were submitted to arylboronic acid in the presence of $\mathrm{PdCl}_{2}$ (XPhos) $)_{2}$ as precatalyst and tetrabutylammonium hydroxide as base under microwave irradiation at $110{ }^{\circ} \mathrm{C}$ (Scheme 5). 
Scheme 4. Limitation in Suzuki-Miyaura coupling and its Solution through the Synthesis of Bis(XPhos)palladium Dichloride as a Precatalyst.

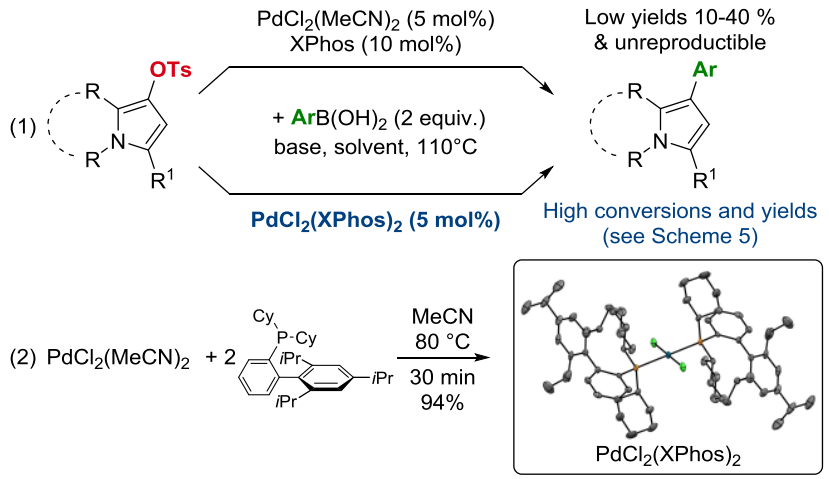

Scheme 5. Scope of Suzuki-Miyaura Cross-Coupling from Various Pyrrolyl Sulfonates 2 and Boronic acids.
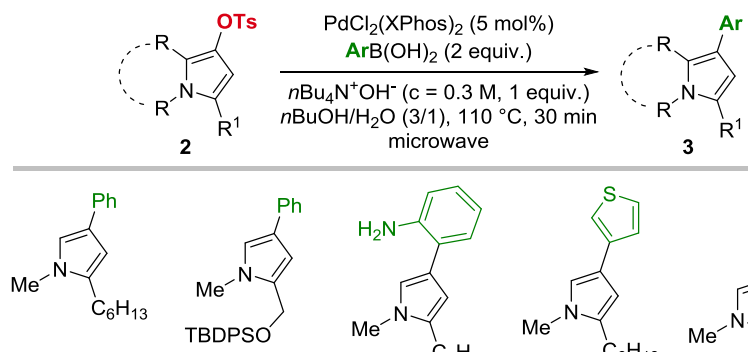

3a, $79 \%$

3a, from OMbs, $71 \% \mathbf{3 b}, 66 \%$
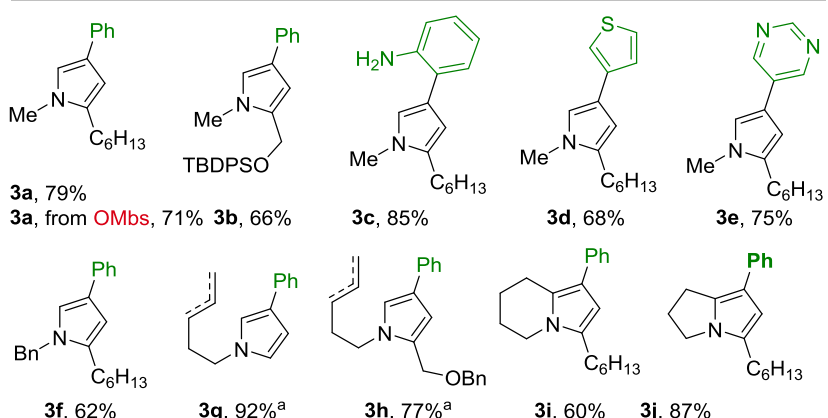

3d, $68 \%$
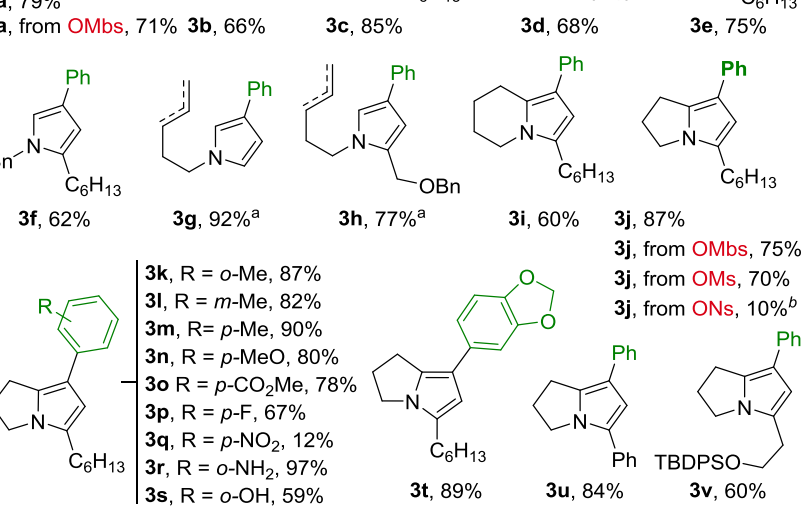

a Cumulative yields of $\mathrm{N}$-pent-4-enyl and $\mathrm{N}$-pent-3-enyl derivatives. $\mathrm{Ts}=\mathrm{Tosyl}$; Mbs = 4-Methoxybenzenesulfonyl; Ms = Mesyl, Ns = Nosyl; TBDPS = $t$-Butyldiphenylsilyl.

${ }^{a}$ Cumulative yields of $\mathrm{N}$-pent-4-enyl and $\mathrm{N}$-pent-3-enyl derivatives. ${ }^{b}$ Yield calculated by integration of the ${ }^{1} \mathrm{H}$ NMR spectrum of the crude product relative to an internal standard (dimethyl terephthalate). Ts = Tosyl; Mbs = 4-Methoxybenzenesulfonyl; Ms = Mesyl, Ns = Nosyl; TBDPS = tert -Butyldiphenylsilyl .

Under such optimal conditions, the simple $N$-methyl pyrrolyl tosylates or 4-methoxybenzenesulfonates 2a-c readily reacted with phenyl boronic acid and provided the expected coupling products 3a-b in good to high yields. Rewardingly for the planned rhazinilam total synthesis, the coupling of $\mathbf{2 a}$ with the non-protected anilinoboronic acid efficiently provided the 2aminophenyl pyrrole $3 \mathbf{c}$ in the highest yield. $\mathbf{3 c}$ indeed corresponds to the key anilinopyrrole motif of the rhazinilam natural product family. The pyrrolyl tosylate $\mathbf{2 a}$ could also be coupled with heteroaromatic boronic acids, leading to the corresponding thienyl and pyrimidyl pyrroles 3d-e in good yields. Pyrrolyl sulfonates carrying $N$-benzyl $2 d$ or pent-4-enyl chain 2e-f were transformed into coupled compounds $\mathbf{3 f}-\mathbf{h}$ in high yields. Under the coupling conditions, isomerization of the double bond occurred for compounds 2e-f leading to inseparable mixtures of 3 regio- and stereoisomers for both products $\mathbf{3 g}$ and $\mathbf{3 h}$.

The dihydropyrrolizine or tetrahydroindolizine sulfonates (3i-v) we already obtained through our gold-catalyzed cycloisomerization-sulfonyl migration cascade ${ }^{6}$ could also be coupled with various boronic acids under the same conditions. Interestingly, para-methoxybenzenesulfonate and mesylate reacted almost as well as the corresponding tosylate, while the nosylate only gave low yield of the coupling product (see the $3 \mathbf{j}$ series). The nosylate group turned to be sensitive to the applied basic conditions. Variations of the electronic density of the arylboronic acid coupling agent did not alter much the coupling efficiency, so far an electron-rich aryl was transferred (see 3n-s vs 3j). Mildly electron withdrawing substituents and even a fluorine were well tolerated (see 3o-p vs $\mathbf{3 j}$ ) and only the strongly withdrawing nitro group diminished the coupling efficiency (see $\mathbf{3 q}$ vs $\mathbf{3 j}$ ). As with monocyclic pyrrole sulfonate, the ortho-anilinoboronic acid efficiently provided the 2-aminophenyl dihydropyrrolizine $\mathbf{3 r}$ in very high yield without the need of protecting group. The same was true for the coupling of the ortho-hydroxyphenylboronic acid, although the yield of the so-obtained 2-hydroxyphenyl dihydropyrrolizine $3 \mathrm{~s}$ was lower. The protected catecholboronic acid provided the expected coupling product $3 \mathbf{t}$ again in high yield.

With the key two first steps of the planned rhazinilam synthesis (steps A and B in Scheme 1) ensured with model compounds, we then embarked on its total synthesis (Scheme 6). Two linear precursors 10-p were prepared in three steps from $N$-tosyl or $N$-4-methoxybenzenesulfonyl glycine methyl esters and the known tert-butyl (E)-4-ethylidene-7-iodoheptanoate ${ }^{15}$ compound respectively (See Supporting Information). The gold-catalyzed cycloisomerization-sulfonyl migration cascade was then performed starting from each derivative under the conditions mentioned above. The expected $N$-alkylated pyrrolyl sulfonates 20-p were efficiently (within $1 \mathrm{~min}$ ) obtained in very high and similar yields.

From these compounds, the two routes were explored. First, Heck-type reaction (Step C in Scheme 1) which would provide the tetrahydroindolizine core of rhazinilam was tested before our Suzuki-Miyaura cross coupling (Step B in Scheme 1). The known conditions, some already used in the synthesis of rhazinilam and related natural products, ${ }^{16}$ only led to degradation. Eventually, a combination of solvents similar to those reported by Trauner, ${ }^{17}$ and with dioxygen as the oxidant at room temperature as in Gaunt's conditions, ${ }^{18}$ allowed formation of the cyclized products $\mathbf{4 a - b}$. However, careful analysis of the product structures revealed that the cyclization occurred at the less nucleophilic carbon 5 of the pyrrole instead of carbon $2,{ }^{19}$ suggesting a C-H activation mechanism. ${ }^{20}$ Furthermore, a large difference in efficiency was observed, as the para-methoxybenzenesulfonate 4 a provided the bicyclic product with high yield, while the tosylate $\mathbf{4 b}$ did it only with low yield (76 vs $25 \%$ ). Nevertheless, coupling $4 \mathbf{a}$ with the unprotected 2-aminophenylboronic acid under our optimized conditions gave the coupling product $\mathbf{3 w}$ in high yield within 30 $\mathrm{min}$, and thus validated this step on rhazinilam-type compounds coupling. 
Scheme 6. Total Synthesis of Rhazinilam.

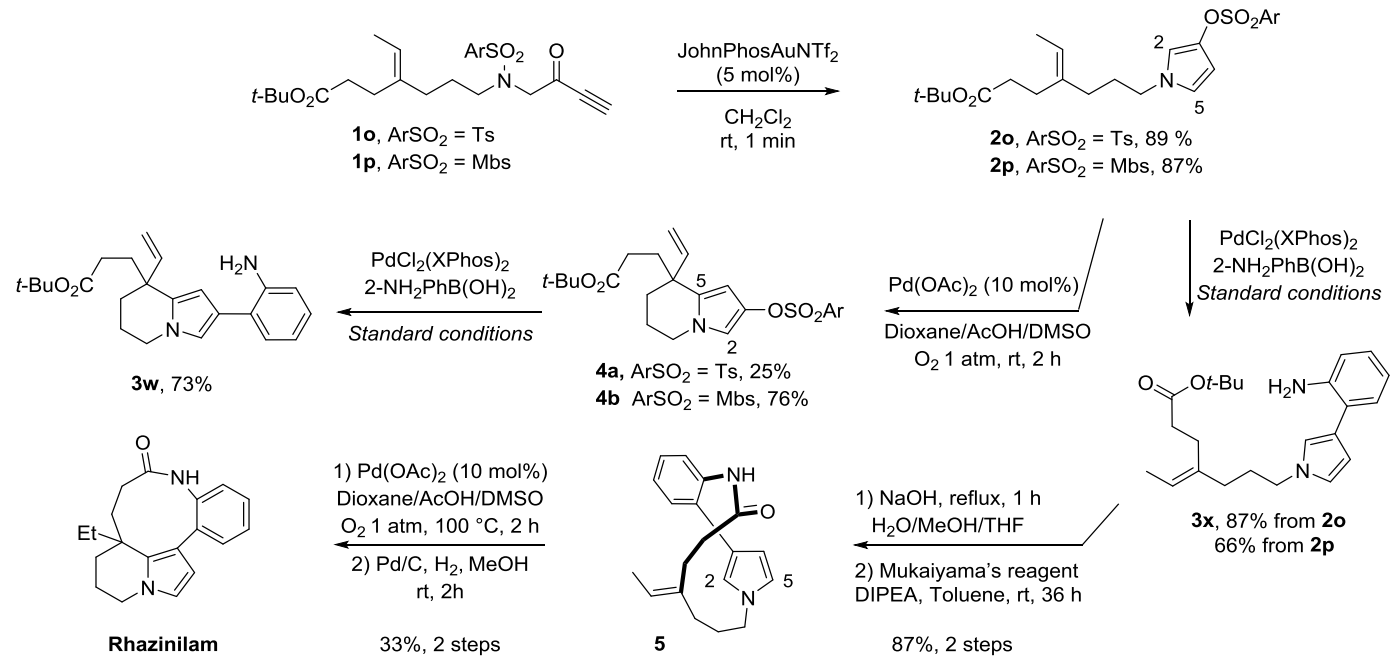

Considering this selectivity issue and inspired by the Zakarian's total synthesis of rhazinilam based on the transannular cyclization of a halogenated 13-membered lac$\operatorname{tam}^{15}$, the reverse sequence was applied to 2o-p. Indeed, due to the macrolactam structure, the alkene moiety lies closer to carbon 2 than to carbon 5 of the pyrrole moiety, suggesting that the ring closure should take place at the desired position for the key Heck-type reaction. The coupling of 2o-p with the unprotected anilinoboronic acid provided the expected 2aminophenyl pyrrole $\mathbf{3 x}$ in excellent yield starting from the tosylate $\mathbf{2 0}$, but in lower yield from $\mathbf{2 p}$. The completion of the synthesis was achieved through macrolactamization, intramolecular oxidative Heck addition and hydrogenation of the resulting vinyl side chain. The macrolactam formation was readily performed according to Zakarian's conditions, ${ }^{15}$ furnishing $\mathbf{5}$ in high overall yields. After several trials, the intrachain Heck-type reaction could only be performed at high temperature using the conditions developed for compound $\mathbf{4 a -}$ b. This allowed the isolation of the expected cyclized product with a moderate yield. Hydrogenation of the latter under conventional conditions quantitatively provided rhazinilam.

In conclusion, we achieved a 16-step synthesis of rhazinilam in its longest linear sequence, which included the preparation of Zakarian's iodoheptanoate precursor ${ }^{15}$ from tert-butyl acrylate. This synthesis allowed us to set up the gold-catalyzed cycloisomerization-sulfonyl migration of $\mathrm{N}$ alkylated $N$-sulfonyl 1-aminobut-3-yn-2-ones to 1,2,4trisubstituted pyrrolyl sulfonates and the first palladiumcatalyzed coupling of pyrrolyl tosylates and related sulfonates.

\section{ASSOCIATED CONTENT}

\section{Supporting Information}

The Supporting Information is available free of charge on the ACS Publications website.

Experimental details, copies of spectra, and additional table of optimization conditions (PDF)

Crystallographic data for complex 3 (CIF, CCDC 1867782)

\section{AUTHOR INFORMATION}

\section{Corresponding Author}

ablanc@unistra.fr

ORCID

Aurélien Blanc: 0000-0003-4240-3281

\section{Notes}

The authors declare no competing financial interests.

\section{ACKNOWLEDGMENT}

We gratefully acknowledge the French Ministry of Research and the CNRS for financial support. F. S. thanks the French Ministry of Research for PhD fellowship. The authors thank Dr Pierre de Frémont (University of Strasbourg) for crystallographic structure refinement of the palladium complex $\mathrm{PdCl}_{2}$ (XPhos $)_{2}$.

\section{REFERENCES}

(1) (a) Hajícek, J. Recent developments in syntheses of the postsecodine indole alkaloids. Part III. rearranged alkaloid types. Collect. Czech. Chem. Commun. 2011, 76, 2023. (b) Ishikura, M.; Yamada, K.; Abe, T. Simple indole alkaloids and those with a non-rearranged monoterpenoid unit. Nat. Prod. Rep. 2010, 27, 1630.

(2) (a) Banerji, A.; Majumder, P. L.; Chatterjee, A. Occurrence of geissoschizine and other minor biogenetically related alkaloids in Rhazya stricta. Phytochemistry 1970, 9, 1491; (b) Linde, H. H. A. Alkaloids of Melodinus australis. Helv. Chim. Acta 1965, 48, 1822; (c) Kam, T.-S.; Yoganathan, K., Three aspidofractinine-type alkaloids from Kopsia teoi. Phytochemistry 1996, 42, 539.

(3) (a) Thoison, O.; Guenard, D.; Sevenet, T.; Kan-Fan, C.; Quirion, J. C.; Husson, H. P.; Deverre, J. R.; Chan, K. C.; Potier, P. Inhibition of tubulin polymerization into microtubules by rhazinilam. C. R. Acad. Sci., Ser. II 1987, 304, 157. (b) David, B.; Sevenet, T.; Morgat, M.; Guenard, D.; Moisand, A.; Tollon, Y.; Thoison, O.; Wright, M. Rhazinilam mimics the cellular effects of taxol by different mechanisms of action. Cell Motil. Cytoskeleton. 1994, 28, 317.

(4) Edler, M. C.; Yang, G.; Katherine Jung, M.; Bai, R.; Bornmann, W. G.; Hamel, E. Demonstration of microtubulelike structures formed with (-)-rhazinilam from purified tubulin outside of cells and a simple tubulin-based assay for evaluation of analog activity. Arch. Biochem. Biophys. 2009, 487, 98.

(5) (a) Kholod, I.; Vallat, O.; Buciumas, A.-M.; Neier, R., Syntheses of rhazinilam. A comparative review of forty years of 
synthetic endeavors. Heterocycles 2011, 82, 917; For recent total syntheses, see: (b) Dagoneau, D.; Xu, Z.; Wang, Q.; Zhu, J., Enantioselective total syntheses of (-)-rhazinilam, (-)leucomidine B, and (+)-leuconodine F. Angew. Chem. Int. Ed. 2016, 55, 760; (c) Zhao, K.; Xu, S.; Pan, C.; Sui, X.; Gu, Z., Catalytically asymmetric $\mathrm{Pd} /$ norbornene catalysis: Enantioselective synthesis of (+)-rhazinal, (+)-rhazinilam, and (+)-kopsiyunnanine C1-3. Org. Lett. 2016, 18, 3782; (d); Magne, V.; Lorton, C.; Marinetti, A.; Guinchard, X.; Voituriez, A. Short enantioselective total synthesis of (-)rhazinilam using a gold(I)-catalyzed cyclization. Org. Lett. 2017, 19, 4794; (e) Shemet, A.; Carreira, E. M. Total synthesis of (-)-rhazinilam and formal synthesis of (+)-eburenine and (+)-aspidospermidine: Asymmetric $\mathrm{Cu}$-catalyzed propargylic substitution. Org. Lett. 2017, 19, 5529.

(6) Miaskiewicz, S.; Gaillard, B.; Kern, N.; Weibel, J-M.; Pale, P.; Blanc, A. Gold(I)-catalyzed $N$-desulfonylative amination versus $N$-to- $O 1,5$-sulfonyl migration: A versatile approach to 1-azabicycloalkanes. Angew. Chem. Int. Ed. 2016, 55, 9088.

(7) Wu, Y.; Suehiro, M.; Kitajima, M.; Matsuzaki, T.; Hashimoto, S.; Nagaoka, M.; Zhang, R.; Takayama, H. Rhazinilam and quebrachamine derivatives from Yunnan Kopsia arborea. J. Nat. Prod. 2009, 72, 204.

(8) (a) Su, Y.; Zhou, H.; Chen, J.; Xu, J.; Wu, X.; Lin, A.; Yao, H. Solvent-controlled switchable C-H alkenylation of 4-aryl1H-pyrrole-3-carboxylates: Application to the total synthesis of ( \pm )-rhazinilam. Org. Lett. 2014, 16, 4884; (b) McMurray, L.; Beck, E. M.; Gaunt, M. J. Chemical synthesis of aspidosperma alkaloids inspired by the reverse of the biosynthesis of the rhazinilam family of natural products. Angew. Chem. Int. Ed. 2012, 51, 9288.

(9) (a) Nguyen, H. N.; Huang, X.; Buchwald, S. L. The first general palladium catalyst for the Suzuki-Miyaura and carbonyl enolate coupling of aryl arenesulfonates. J. Am. Chem. Soc. 2003, 125, 11818; (b) Bhayana, B.; Fors, B. P.; Buchwald, S. L. A versatile catalyst system for Suzuki-Miyaura crosscoupling reactions of $\mathrm{C}\left(\mathrm{sp}^{2}\right)$-tosylates and mesylates. Org. Lett. 2009, 11, 3954; (c) Yang, J.; Liu, S.; Zheng, J.-F.; Zhou, J. Room-temperature Suzuki-Miyaura coupling of heteroaryl chlorides and tosylates. Eur. J. Org. Chem. 2012, 6248; (d) Quan, Z.-J.; Jing, F.-Q.; Zhang, Z.; Da, Y.-X.; Wang, X.-C. Palladium(II) catalyzed Suzuki/Sonogashira cross-coupling reactions of sulfonates: an efficient approach to $\mathrm{C} 2$ functionalized pyrimidines and pyridines. Eur. J. Org. Chem. 2013, 7175.

(10) Isobe, K.; Nanjo, K.; Nakamura, Y.; Kawaguchi, S. Organopalladium(II) complexes containing carbon-bonded heterocycles as a ligand. Bull. Chem. Soc. Jpn. 1986, 59, 2141; (b) Nakatsu, K.; Kinoshita, K.; Kanda, H.; Isobe, K.; Nakamura, Y.; Kawaguchi, S. X-ray molecular structure of a pyridyl-bridged dinuclear palladium complex, $\operatorname{trans}(P, N)$ bis[bromo( $\mu$-pyridyl-

C2,N)(triphenylphosphine)palladium(II)]. Chem. Lett. 1980, 913
(11) Amatore, C.; Le Duc, G.; Jutand, A. Mechanism of palladium-catalyzed Suzuki-Miyaura reactions: Multiple and antagonistic roles of anionic "bases" and their countercations. Chem. Eur. J. 2013, 19, 10082

(12) (a) Ogata, T.; Hartwig, J. F. Palladium-catalyzed amination of aryl and heteroaryl tosylates at room temperature. J. Am. Chem. Soc. 2008, 130, 13848. (b) Kinzel, T.; Zhang, Y. Buchwald, S. L. A new palladium precatalyst allows for the fast Suzuki-Miyaura coupling reactions of unstable polyfluorophenyl and 2-heteroaryl boronic acids. J. Am. Chem. Soc. 2010, 132, 14073.

(13) Kashin, A. S.; Ananikov, V. P. Catalytic C-C and Cheteroatom bond formation reactions: in situ generated or preformed catalysts? Complicated mechanistic picture behind well-known experimental procedures. J. Org. Chem. 2013, 78, 11117.

(14) Precatalyst $\mathrm{PdCl}_{2}(\mathrm{XPhos})_{2}$ complex has been reported once for comparison purposes: Yang, Y.; Lim, J. F. Y.; Chew, X.; Robins, E. G.; Johannes, C. W.; Lim, Y. H.; Jong, H. Palladium precatalysts containing meta-terarylphosphine ligands for expedient copper-free Sonogashira cross-coupling reactions. Catal. Sci. \& Technol. 2015, 5, 3501.

(15) Gu, Z.; Zakarian, A. Total synthesis of rhazinilam: axial to point chirality transfer in an enantiospecific Pd-catalyzed transannular cyclization. Org. Lett. 2010, 12, 4224.

(16) (a) Ferreira, E. M.; Stoltz, B. M., Catalytic C-H bond functionalization with palladium(II): Aerobic oxidative annulations of indoles. J. Am. Chem. Soc. 2003, 125, 9578; (b) Beck, E. M.; Grimster, N. P.; Hatley, R.; Gaunt, M. J., Mild aerobic oxidative palladium(II) catalyzed $\mathrm{C}-\mathrm{H}$ bond functionalization: Regioselective and switchable $\mathrm{C}-\mathrm{H}$ alkenylation and annulation of pyrroles. J. Am. Chem. Soc. 2006, 128, 2528; (c) Gao, S.; Yang, C.; Huang, Y.; Zhao, L.; Wu, X.; Yao, H.; Lin, A., $\mathrm{Pd}(\mathrm{II})$-catalyzed intramolecular oxidative Heck dearomative reaction: approach to thiazole-fused pyrrolidinones with a $\mathrm{C} 2$ azaquarternary center. Org. Biomol. Chem. 2016, 14, 840 .

(17) Bowie, A. L.; Trauner, D. Total synthesis of ( \pm )-rhazinal using novel palladium-catalyzed cyclizations. J. Org. Chem. 2009, 74, 1581.

(18) McMurray, L.; Beck, E. M.; Gaunt, M. J. Chemical synthesis of aspidosperma alkaloids inspired by the reverse of the biosynthesis of the rhazinilam family of natural products. Angew. Chem. Int. Ed. 2012, 51, 9288.

(19) Kromann, J. C.; Jensen, J., H.; Kruszyk, M.; Jessing, M.; Jorgensen, M.; Kruszyk, M., Fast and accurate prediction of the regioselectivity of electrophilic aromatic substitution reactions. Chem. Sci. 2018, 9, 660.

(20) Zhang, H.; Ferreira, E. M.; Stoltz, B. M., Pd-catalyzed cyclizations: Direct oxidative Heck cyclizations: Intramolecular Fujiwara-Moritani arylations for the synthesis of functionalized benzofurans and dihydrobenzofurans. Angew. Chem. Int. Ed. 2004, 43, 6144. 